\title{
Discussion: Potential for carfree development in the UK
}

Steven Melia PhD

Senior Lecturer, Centre for Transport and Society, University of the West of England, Bristol, UK

Hugh Barton MPhil, DipTP, MRTPI

Professor, WHO Healthy Cities Collaborating Centre, University of the West of England, Bristol, UK

Graham Parkhurst PhD

Professor, Centre for Transport and Society, University of the West of England, Bristol, UK
Marcus P. Enoch MSc (Eng), PhD, CMILT, FHEA

Senior Lecturer, Transport Studies Group, School of Civil and Building Engineering, Loughborough University, Loughborough, UK

James P. Warren PhD, FHEA, AMICE, MDRS

Senior Lecturer, Department of Engineering and Innovation, The Open University, Milton Keynes, UK

\section{Contribution by M. P. Enoch and J. P. Warren}

On reading the interesting article 'Potential for carfree development in the UK' by Melia et al. (2013), the contributors were struck by the notion that nowhere in the extant literature is there a comprehensive taxonomy of what might be termed 'carfree communities' in the most general sense. As a tentative first step in this direction, 10 possible criteria to consider are proposed.

The first relates to the degree or level of 'carfreeness' in a community and whether the emphasis is on either ownership or use, or both (Melia, 2010). For instance, in some cases, car ownership is entirely forbidden while in others car use may merely be deterred at particular times of day by the imposition of access charges (Litman, 2012).

The second is the spatial size of such 'communities', which might range from certain types of vehicle being denied entry to a single site or road facility (such as the Strøget shopping street in Copenhagen, Denmark), right up to a town (Venice, Italy) or even potentially a region or nation (Cuba) being entirely 'carfree' (Crawford, 2000; Wright, 2005).

Third, carfree/-reduced communities can be categorised by their degree of permanence. Thus, such communities can exist over a range of timescales from quite short-term episodes (e.g. where a road is closed off for an afternoon to host a street market), through medium-term controls (say where a bridge is closed to traffic for structural repairs), to situations where restrictions on vehicles are permanent (Cairns et al., 1998; Wright, 2005).

The fourth is whether carfree/-reduced communities occur on a planned and regular basis or whether they are more reactive and/or irregular or 'one-off' events (Cairns et al., 1998; Wright, 2005).
Fifth, it is interesting to look at the reasons or motivations for establishing carfree/-reduced communities, which can be thought of as meeting specific local needs and/or addressing broader social, economic or environmental concerns. For example, carfree developments have evolved in London due to restricted space for parking coupled with already low levels of car ownership and relatively good public transport (Morris et al., 2009), while (almost) carfree communities emerged throughout Cuba in the early 1990s due to the economic and political context (Enoch et al., 2004), and the Amish community in North America chooses to remain carfree for religious reasons (Wagler, undated).

Sixth, there are several means by which carfree/-reduced communities have been enforced. These include moral as well as physical, regulatory and fiscal mechanisms (Scheurer, 2001). Thus, community pressures enforce carfreeness in Amish communities, whereas physical barriers prevent car access to the island of Sark in the English Channel, for example.

The seventh is the 'type of boundary', whether physical, institutional, socioeconomic, cultural or a combination of these. Many carfree areas are physically isolated by being islands surrounded by water or due to 'difficult' terrain (e.g. Venice or Clovelly in Devon, UK) or are institutionally defined, such as the congestion charging zone in Valletta, Malta (Attard and Enoch, 2011).

The eighth is the 'permeability' of the boundary; that is, the degree to which carfreeness is 'enforced' within the carfree community - a characteristic that is probably influenced by the means of enforcement and the type of boundary in particular.

The ninth concerns the roles of the different stakeholders involved in establishing such a community. In particular, whether the process was imposed by a government agency or 
landowner in a top-down manner (as in the case of Sark) or was generated from within the community itself from the bottom up (as in the Christiania area of Copenhagen) (Litman, 2012; Morris et al., 2009).

Finally, the tenth is the nature of the broader context within which each carfree/-reduced community developed in terms of whether the surroundings are in any way 'special' or unique and thus more likely to support a measure that seeks to limit car ownership and/or use. Once again, the Cuba example is pertinent here (Enoch et al., 2004), as are the cases of Venice, Italy and Mont Saint-Michel just off the coast of Normandy, France, which - for geographical and historical reasons - have so far remained carfree (Crawford, 2000).

\section{REFERENCES}

Attard M and Enoch MP (2011) Policy transfer and the introduction of road pricing in Valletta, Malta. Transport Policy 18(3): 544-553.

Cairns S, Hass-Klau C and Goodwin P (1998) Traffic Impact of Highway Capacity Reductions. Landor Publishing, London, UK.

Crawford JH (2000) Car Free Cities. International Books, Utrecht, the Netherlands.

Enoch MP, Warren JP, Valdes Rios $\mathrm{H}$ and Henriquez Menoyo E (2004) The effect of economic restrictions on transport practices in Cuba. Transport Policy 11(1): 67-76.
Litman T (2012) Car-Free Planning: Reducing Automobile Travel at Particular Times and Places, Chapter 6, TDM Encyclopaedia. Victoria Transport Policy Institute, Victoria BC, Canada. See http://www.vtpi.org (accessed $19 / 04 / 2013)$

Melia S (2010) Carfree, low car - what's the difference? European Transport Conference, Glasgow, UK.

Melia S, Barton H and Parkhurst G (2013) Potential for carfree development in the UK. Proceedings of the Institution of Civil Engineers - Urban Design and Planning 166(2): 136-145, http://dx.doi.org/10.1680/udap.10.00048.

Morris D, Enoch MP, Pitfield DE and Ison SG (2009) Car-free development through UK community travel plans. Proceedings of the Institution of Civil Engineers - Urban Design and Planning 162(1): 19-27, http://dx.doi.org/10. 1680/udap.2009.162.1.19.

Scheurer J (2001) Urban Ecology, Innovations in Housing Policy and the Future of Cities: Towards Sustainability in Neighbourhood Communities. PhD thesis, Murdoch University, Perth, WA, Australia.

Wagler D (undated) Are all Things Lawful? Pathway Publishing, Aylmer, ON, Canada.

Wright L (2005) Sustainable Transport: A Sourcebook for Policy-makers in Developing Cities, Module 3e, Car Free Development. Gesellschaft fur Technische Zusammenarbeit, Eschborn, Germany.

\section{WHAT DO YOU THINK?}

To discuss this paper, please email up to 500 words to the editor at journals@ice.org.uk. Your contribution will be forwarded to the author(s) for a reply and, if considered appropriate by the editorial panel, will be published as discussion in a future issue of the journal.

Proceedings journals rely entirely on contributions sent in by civil engineering professionals, academics and students. Papers should be 2000-5000 words long (briefing papers should be 1000-2000 words long), with adequate illustrations and references. You can submit your paper online via www.icevirtuallibrary.com/content/journals, where you will also find detailed author guidelines. 